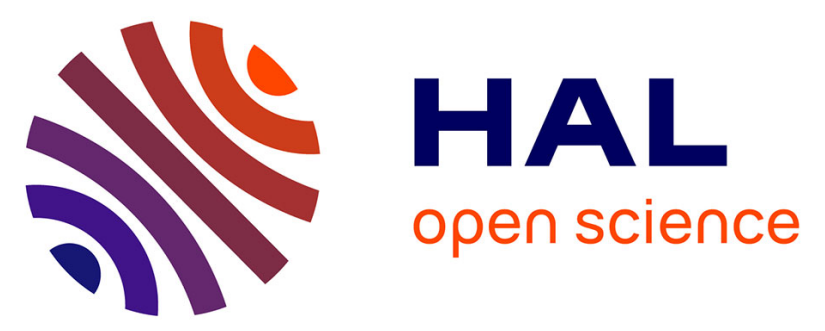

\title{
Gas Extraction From Polar Ice Cores: A Critical Issue For Studying The Evolution of Atmospheric CO2 and Ice-Sheet Surface Elevation
}

Dominique Raynaud, Robert Delmas, Jean-Marc Ascencio, Michel Legrand

\section{- To cite this version:}

Dominique Raynaud, Robert Delmas, Jean-Marc Ascencio, Michel Legrand. Gas Extraction From Polar Ice Cores: A Critical Issue For Studying The Evolution of Atmospheric CO2 and Ice-Sheet Surface Elevation. Annals of Glaciology, 1982, 3, pp.265-268. 10.3189/S0260305500002895 . hal03512164

\author{
HAL Id: hal-03512164 \\ https://hal.science/hal-03512164
}

Submitted on 5 Jan 2022

HAL is a multi-disciplinary open access archive for the deposit and dissemination of scientific research documents, whether they are published or not. The documents may come from teaching and research institutions in France or abroad, or from public or private research centers.
L'archive ouverte pluridisciplinaire $\mathbf{H A L}$, est destinée au dépôt et à la diffusion de documents scientifiques de niveau recherche, publiés ou non, émanant des établissements d'enseignement et de recherche français ou étrangers, des laboratoires publics ou privés.

\section{(ㅇ)(1) $\$$}

Distributed under a Creative Commons Attribution - NonCommerciall 4.0 International 


\title{
GAS EXTRACTION FROM POLAR ICE CORES: A CRITICAL
}

\section{ISSUE FOR STUDYING THE EVOLUTION OF ATMOSPHERIC}

\section{$\mathrm{CO}_{2}$ AND ICE-SHEET SURFACE ELEVATION}

\author{
by \\ D. Raynaud, R. Delmas, J. M. Ascencio* and M. Legrand \\ (Laboratoire de Glaciologie et Géophysique de l'Environnment, 2 rue Très-Cloîtres, \\ 38031 Grenoble-Cedex, France)
}

\section{ABSTRACT}

The measurement of gases enclosed in polar ice cores provides valuable information concerning the history of the ice sheets and their environment. The extraction of gases from ice is a critical step in the experimental procedure. We found that the most efficient methods of gas extraction for 20 to $50 \mathrm{~g}$ samples were ice melting and controlled refreezing of the melt water for the total gas content and ice crushing for the $\mathrm{CO}_{2}$ content. These two experimental methods are described in detail.

It is shown, in particular, that ice is easily contaminated by carbonate dust during sample preparation. This contamination introduces an excess of $\mathrm{CO}_{2}$ when gases are extracted using a procedure involving ice melting.

\section{INTRODUCTION}

When firn is transformed into air-tight ice by natural sintering of firn grains near the ice surface, a portion of the surrounding atmosphere becomes trapped in the pores between the grains. The barometric conditions and the gaseous composition of the atmosphere prevalling when the firn pores close of $f$ are thus reflected in the volume and composition of the air enclosed in the ice. Consequently, measurements of gases enclosed in polar ice cores provide valuable information about the past history and environment of the ice sheets, including past surface elevations of the ice sheets from the total gas content (Raynaud and Lebel 1979, Raynaud and others 1979, Raynaud and Whillans 1982), and the evolution of the atmospheric $\mathrm{CO}_{2}$ over the last tens of thousands of years from the $\mathrm{CO}_{2}$ content (Berner and others 1980, Delmas and others 1980).

Nevertheless, a portion of the gases extracted from ice may have an origin different from the gaseous atmosphere trapped during ice formation. Solid trace constituents may be decomposed and generate gases during gas extraction. Actually, extraction of gases from ice is the most critical step in the experimental procedure. The aim of this paper is to review the different methods tested in our laboratory and to describe and discuss in detail those which appear to be the most efficient.
2. GAS EXTRACTION FOR THE VOLUMETRIC DETERMINATION OF THE AIR TRAPPED IN ICE

The first requirement for measuring accurately the volume of atmospheric air enclosed in ice is to achieve a complete extraction. The total gas content $\checkmark$ measured in cold polar ice is of the order of $0.1 \mathrm{~cm}^{3}=100 \mathrm{~mm}^{3}$ STP $\mathrm{g}^{-1}$ of ice. The natural variations observed are generally a few per cent of $v$. The composition of the total gas is very close to the atmospheric composition, except for $\mathrm{CO}_{2}$. This $\mathrm{CO}_{2}$ deviation, due to the decomposition of contaminating carbonate dust (section 3 ), is too small (about $0.1 \%$ of the total volume) to affect air volume measurements.

For total gas content determinations, we used two extraction methods: melting of ice in kerosene, and extraction of gases in a vacuum. The first method is described in detail by Langway (1958). The experimental uncertainty is about $\pm 7 \%$. The study of $V$ variations in ice generally requires more accurate measurements, which are obtained by extracting the gases in a vacuum.

We have tested and used the latter method in our laboratory, following several different procedures (Raynaud 1977, Raynaud and Delmas 1977, Lebel 1979): (i) sublimating ice, ( $i j$ melting $i c e$, and ( $i i i)$ melting ice and refreezing the melt water. All these procedures generally lead to accurate ( \pm about $1 \%$ ) relative measurements, but there are systematic differences between results obtained with different procedures (Raynaud and Lebel 1979). Because of the systematic nature of these differences, the total gas content variations in ice deduced from the results of a single procedure are not affected and $V$ changes obtained by different procedures may be compared. A major difference between the procedures tested is the amount of water vapour in contact with the drying agent $\left(\mathrm{P}_{2} \mathrm{O}_{5}\right.$ or $\left.\mathrm{Mg}\left(\mathrm{ClO}_{4}\right)_{2}\right)$ or trapped by condensation (in a cold trap) during gas extraction. Gas-solid interactions occurring during trapping of water vapour are probably the main cause of the systematic differences observed between the different procedures. Currently we use the procedure involving ice melting and refreezing. This procedure reduces considerably the amount of water vapour in contact with the drying agent and is the most efficient (best

*Present address: Centre des Faibles Radioactivitēs du CNRS, 91190 Gif sur Yvette, France. 
relative precision and least time-consuming). The analytical method has already been described in Lebel (1979) and was used, in particular, for measurements reported by Raynaud and Lebel (1979) and Raynaud and Whillans (1982).

The main steps in the procedure are as follows. (i) At about $-15^{\circ} \mathrm{C}$, the ice sample is prepared, weighed accurately (20 to $25 \pm 0.01 \mathrm{~g})$ and placed in a glass vessel ((1) in Fig.1). (ii) With the extraction line (Fig.1) pre-evacuated, the glass vessel is connected to the line and evacuated for $20 \mathrm{~min}$ through the liquid $N_{2}$-trap (9). Then the stopcock of (1) is closed and the ice melts. (iii) During melting, most of the gases escape above the melt water and a certain gas fraction remains dissolved. The water is then slowly refrozen (refreezing time is 30 to $40 \mathrm{mins}$ ). Cooling is obtained by the Peltier effect with thermoelectric modules. The bottom of the vessel is especially designed in order to provide a perfect contact with the top of the modules. In this way, dissolved gases migrate towards the ice-water interface as the ice grows and at the end of the refreezing process the vessel contains gas-free ice with the extracted gases above. (iv) The stopcock of (1) is opened again, the extracted air dried through the $\mathrm{P}_{2} \mathrm{O}_{5}$ traps (4) and collected in a volumetric gas burette (6) using an automatic Toepler pump (5). During this last step, only a small amount of water vapor is transferred to the $\mathrm{P}_{2} \mathrm{O}_{5}$ traps because water in the glass vessel is in the form of ice maintained at low temperature. The traps (4) are filled with granular $\mathrm{P}_{2} 0_{5}$. To obtain reproducible results, the $\mathrm{P}_{2} \mathrm{O}_{5}$ has to be changed after about 20 extractions.

The amount of gas that can be extracted by a second ice melting-controlled refreezing cycle is negligible $(0.1$ to $0.3 \%$ of the total amount of gas) and we can assume that gas extraction is complete after only one cycle.

Sources of experimental error in the relative measurements of total gas content in ice are mainly the amount of ice sublimated when the glass vessel (1) is first evacuated and the accuracy of the volumetric burette. The influence of these sources of error was evaluated experimentally and the corresponding experimental error on the $V$ results is $< \pm 1 \%$.

To check the relative precision of our measurements, we performed comparative determinations of $v$ on natural samples which are assumed to enclose very similar amounts of air (Raynaud and Lebel 1979). The

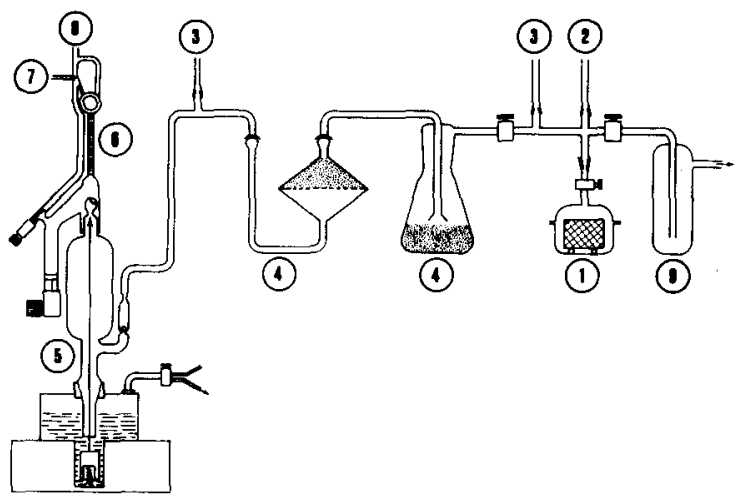

Fig.1. Standard gas extraction line used for total gas content and $\mathrm{CO}_{2}$ measurements.

(1) sample vesseî,

(2) inlet for gas calibration,

(3) Pirani gauge,

(4) $\mathrm{P}_{2} \mathrm{O}_{5}$-trap,

(5) Toepler pump,

(6) gas burette with divisions of $0.02 \mathrm{~cm}^{3}$ STP,

(7) outlet towards the gas chronatograph,

(8) outlet towards the atmosphere,

(9) 1 iquid $N_{2}$-trap. difference between comparable measurements never exceeds $2 \%$ and is on the average $0.7 \%$.

\section{GAS EXTRACTION AND $\mathrm{CO}_{2}$ CONTENT IN POLAR ICE}

\subsection{Carbonates and the contamination problem}

Based on a present-day atmospheric $\mathrm{CO}_{2}$ concentration of 340 parts per million by volume (vpm) and a total gas content in ice of $0.1 \mathrm{~cm}^{3}$ STP $\mathrm{g}^{-1}$, the calculated volume of $\mathrm{CO}_{2}$ in $1 \mathrm{~kg}$ of ice would be 34 ue of $\mathrm{CO}_{2}$, i.e. 1.5 umol. This value is comparable with the concentrations (range 0.5 to $4 \mu \mathrm{mol} \mathrm{kg}^{-1}$ ) of the other major trace constituents or ions $\mathrm{CH}^{+}$, $\mathrm{SO}_{4}{ }^{-}, \mathrm{NO}_{3}{ }^{-}, \mathrm{Cl}^{-}, \mathrm{Na}^{+}$) generally found in Antarctic ice (Delmas and others in press). The determination of chemical concentrations at such low levels is very difficult, mainly because of contamination problems during sampling, sample handling, and laboratory work.

In the case of major atmospheric gases $\left(\mathrm{N}_{2}, \mathrm{O}_{2}\right.$, $\mathrm{Ar}$, and $\left.\mathrm{CO}_{2}\right)$, such problems have been disregarded until now. However, the case of $\mathrm{CO}_{2}$ is special as it can be generated from carbonates. Carbonate is a common constituent of continental dust, particularly in sedimentary areas where it is a significant neutralizing agent of natural atmospheric acids. If care is not taken in sample preparation, carbonate dust may be inadvertently incorporated in the ice, most likely in the form of solid particles deposited on the surface.

If the gases are extracted by ice melting, carbonated particles remain in the melt water in a soluble or insoluble form. These particles may then slowly react with the natural acidity of the sample or be rapidly destroyed by sulphuric acid which may be added to the melt water in order to improve extraction of $\mathrm{CO}_{2}$ (Raynaud and Delmas 1977).

When a carbonate $\left(\mathrm{CO}_{3}{ }^{-}\right)$or bicarbonate $\left(\mathrm{HCO}_{3}{ }^{-}\right)$ dissolves in acidic water, the following equilibria occur:

$$
\begin{aligned}
& \mathrm{CO}_{3}{ }^{2-} \text { (or } \mathrm{HCO}_{3}^{-} \text {) }+2 \mathrm{H}^{+}\left(\text {or } \mathrm{H}^{+}\right) \stackrel{\mathrm{H}_{2} \mathrm{CO}_{3} \text { (carbonic }}{\text { ac }} \\
& \mathrm{H}_{2} \mathrm{CO}_{3} \rightarrow \mathrm{CO}_{2}, \mathrm{H}_{2} \mathrm{O}+\mathrm{CO}_{2}+\mathrm{H}_{2} \mathrm{O} . \\
& \text { dissoived }
\end{aligned}
$$

The more acid the solution, the more easily these equilibria are displaced to the right and $\mathrm{CO}_{2}$ is freed. It can be calculated that $106 \mathrm{\mu g}(1 \mathrm{\mu mol})$ of sodium carbonate decomposes giving $22 \mu l$ (STP) of $\mathrm{CO}_{2}$. This value must be compared to a "normal" $\mathrm{CO}_{2}$ content of ice $\left(\sim 34 \mu \mathrm{L}\right.$ of $\left.\mathrm{CO}_{2}, 1.5 \mu \mathrm{mol}\right)$. If special care is not taken in handling the ice sample, a contamination of $1 \mu \mathrm{mol}$ is very feasible. In this case, the measured $\mathrm{CO}_{2}$ content is increased by $66 \%$.

our present knowledge of the chemical composition (Delmas and others in press) of Antarctic snow clearly demonstrates that natural carbonates are highly improbable in snow, particularly at central Antarctic locations, and have never been detected in clean samples (Legrand 1980). Only contaminated samples have been found to be carbonated. This contamination was assessed by titrating in detail the carbonate or acid content of an ice core (Dome $C$, $111 \mathrm{~m}$ depth). It was shown that it is a typical surface contamination, probably caused by handling the sample in the cold room during band-saw trimming. The sample (a cube of ice) was placed in a clean glass funnel and allowed to melt slowly. Several successive melt-water fractions were recovered and titrated separately. The titration method used, which was developed in our laboratory (Legrand and others to be published*), measures the concentrations $\left( \pm 0.2\right.$ uEquiv. $\left.\ell^{-1}\right)$ of strong acids $(\mathrm{pH}<7)$ or of (bi)carbonates ( $\mathrm{pH}>7$ ) in natural precipitations. In this titration method, the influence of atmospheric $\mathrm{CO}_{2}$ is eliminated.

* Submitted for publication: Legrand M, Aristarain A, Delmas R Acid titration of polar snow. Analytical Chemistry 


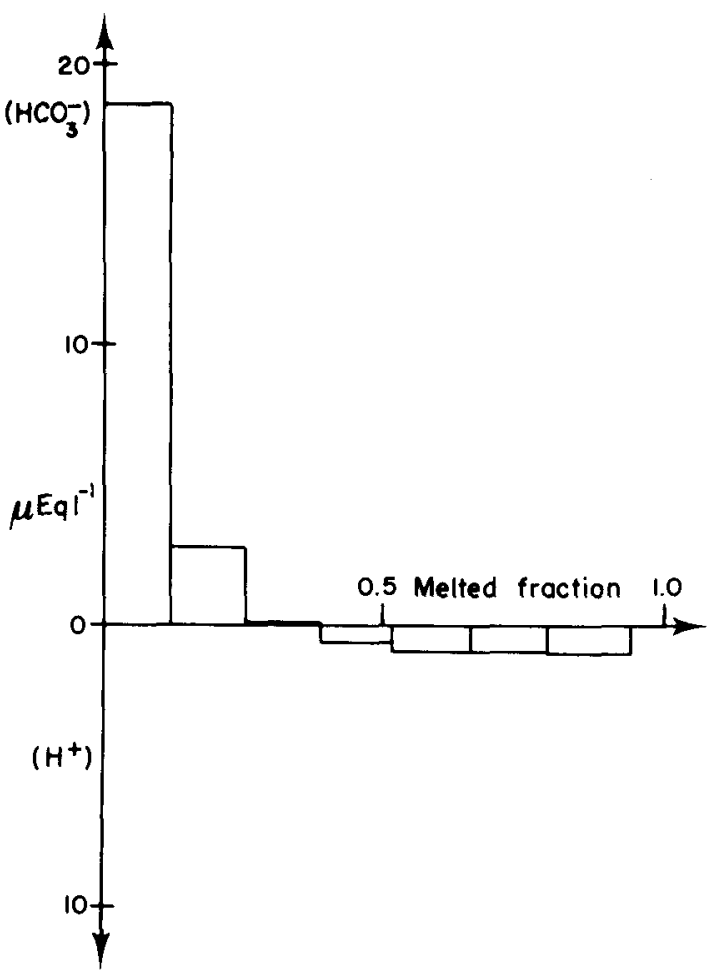

Fig.2. Study of the superficial carbonate contamination of an ice-core sample. The first fractions of melt water recovered contain (bi)carbonates. The inner part of the core is slightly acid and is most probabiy free of contamination.

The diagram in Figure 2 clearly demonstrates that the external part of the ice sample is heavily contaminated and that the "normal" acidity of the ice can be obtained only by analysing the inner core of the sample cube. By adding the (bi)carbonate found for each fraction, we calculate a corresponding total amount of $\mathrm{CO}_{2}$ of nearly 2.2 umol, an amount which can be compared to that which is assumed to be in the air bubbles $(1.5 \mu \mathrm{mo} 1)$. This comparison clearly shows that the measured carbonate contamination may easily double the natural $\mathrm{CO}_{2}$ content of the ice. In this particular case, the $\mathrm{CO}_{2}$ content determined after melting the sample and extracting the gases would probably be higher than $800 \mathrm{vpm}$.

When the sample is not prepared just before gas extraction, contamination may be even more important and explain the very high $\mathrm{CO}_{2}$ values found by Raynaud and Delmas (1977) for certain levels in the Camp Century core. On the other hand, if the volume of the sample is bigger ( $300 \mathrm{~g}$, for example (Berner and others 1980)), surface contamination may be reduced and corresponding excess $\mathrm{CO}_{2}$ lowered. It must be noted that the long complete extraction times ( $>1 \mathrm{~h}$ ) reported by these authors is most probably explained by slow destruction of the carbonated particles and displacement of the above chemical equilibria (Stum and Morgan 1970) by the natural acidity of the melt water. The composition of the "first fraction" (as defined by Berner and others (1980)) can be assumed to approximately reflect that of the bubbles.

We therefore conclude that excess $\mathrm{CO}_{2}$ generally measured when gases are extracted by melting ice is satisfactorily explained by inadvertent contamination of ice samples during preparation. Furthermore, dispersion of the $\mathrm{CO}_{2}$ values thus obtained could be also linked to this artifact.

Preparation of samples in ultraclean conditions at $-15^{\circ} \mathrm{C}$ being difficult, we tried to wash thoroughly the solid sample with a pure liquid (alcohol, de- ionized water, and acidified deionized water were used) in order to remove superficial contaminated ice 1 ayers. The $\mathrm{CO}_{2}$ content of the extracted gases was considerably lowered. It seemed, however, that a residual contamination still remained (Delmas and others 1980).

3.2 Crushing the ice

We have developed a gas extraction method where the ice remains in the solid state in order to recover only the bubbles. By this means, the solid carbonates and the natural acids of the ice are not allowed to react and to free excess $\mathrm{CO}_{2}$.

The ice samples are cut from the centre of the core with a band-saw. Their weights are in the range 30 to $50 \mathrm{~g}$. All operations are done in a cold room (cutting at $-15^{\circ} \mathrm{C}$, crushing at $-40^{\circ} \mathrm{C}$ ). The stainless steel cylindrical container (volume $150 \mathrm{ml}$ ), in which the ice is crushed, has two distinct parts (Fig.3).

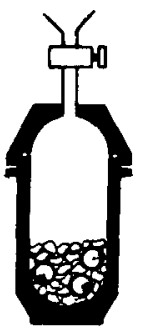

Fig.3. Stainless-steel container used to crush ice samples and recover air from the bubbles.

A stopcock was fitted at the top of the upper part. The assembly of the two parts is made airtight using an indium wire. Stainless-steel balls are added to the solid sample. The air is rapidly evacuated by connecting the container, maintained at about $-40^{\circ} \mathrm{C}$, to the vacuum 1 ine $\left(10^{-2}\right.$ torr $)$. The evacuated vessel is then closed, transferred to the cold room and mounted on the crushing apparatus. This apparatus acts by imparting an up-and-down motion (severa) hundred cycles $\mathrm{min}^{-1}$ ) to the vessel. The ice is very finely pulverized by the metal balls. The optimal crushing time was determined experimentally (Fig.4). After $30 \mathrm{~s}$ the amount extracted is relatively small. Note that the $\mathrm{CO}_{2}$ content measured depends neither on extraction rate nor on crushing time. This shows that a total extraction of the air bubbles is not necessary to get reproducible $\mathrm{CO}_{2}$ values. Finally, by adding a small amount of $\mathrm{NaHCO}_{3}$ powder to the ice sample just before crushing, it was checked that solid contaminants do not alter the $\mathrm{CO}_{2}$ measurements.

After crushing, the stainless-steel container (maintained at about $-40^{\circ} \mathrm{C}$ ) is connected to the extraction line. Extracted gases are dried and collected in the gas burette as described in section 2. $\mathrm{CO}_{2}$ concentrations are measured by gas chromatography (Silicagel column, thermistor detector). The method is calibrated by using synthetic air standards with $\mathrm{CO}_{2}$ contents in the 150 to $400 \mathrm{vpm}$ range. The overall error of the method is estimated to be about $10 \% \star$.

This procedure was used by Delmas and others (1980) in order to describe past variations of atmospheric $\mathrm{CO}_{2} \cdot \mathrm{CO}_{2}$ values thus obtained from ice (160 to $350 \mathrm{vpm}$ ) bracket the present-day $\mathrm{CO}_{2}$ atmospheric content. Furthermore, very similar profiles $\left(\mathrm{CO}_{2}\right.$ concentrations vs age) were obtained at two different Antarctic locations. These results are a

* We are currently improving the chronatographic deterinination method in order to reduce the experimental error. 

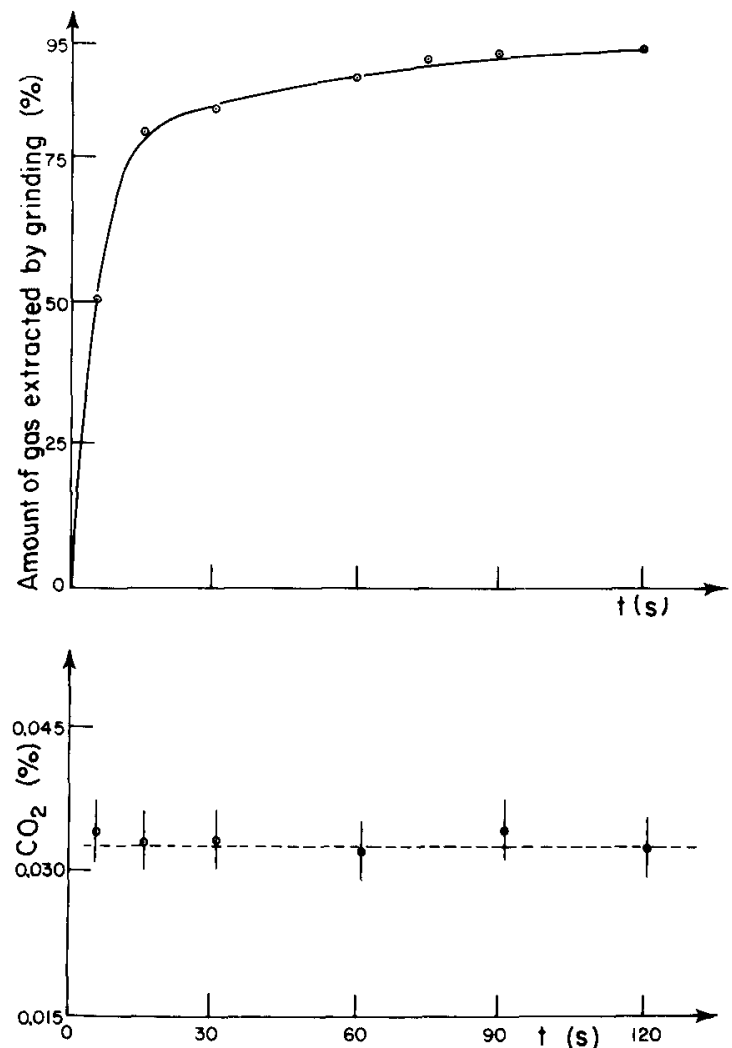

Fig.4. Extraction rates and $\mathrm{CO}_{2}$ content of gases extracted after increasing crushing times (Dome C ice, $111 \mathrm{~m}$ depth).

good indication that the $\mathrm{CO}_{2}$ variations in the air bubbles of polar ice are related to the composition of the past atmosphere.

\section{CONCLUSION}

For measuring the volume of atmospheric air trapped in polar ice, the most suitable and reproducible gas extraction method tested in our laboratory consists of melting the ice and controlled refreezing of the melt water in a vacuum.

In the case of $\mathrm{CO}_{2}$ measurements in ice, carbonate contamination during sample preparation satisfactorily explains the high $\mathrm{CO}_{2}$ values formerly observed. This contamination precludes the use of gas extraction methods involving ice melting, at least in the case of small samples. Ice crushing in a vacuum appears to be the most suitable means of obtaining consistent past atmospheric $\mathrm{CO}_{2}$ values from polar ice.

\section{ACKNOWLEDGEMENTS}

This work was partly undertaken through a contract with the European Economic Community.

\section{REFERENCES}

Berner W, 0eschger $H$, Stauffer B 1980 Information on the $\mathrm{CO}_{3}$ cycle from ice core studies. Radiocarbon 22(2): 227-235

Delmas R J, Ascencio J M, Legrand M 1980 Polar ice evidence that atmospheric $\mathrm{CO}_{2} 20,000$ yr BP was $50 \%$ of present. Nature 284(5752): 155-157

Delmas $R J$, Briat $M$, Legrand $M$ In press. Chemical composition of south polar snow. Joumal of Geophysical Researeh

Langway C C Jr 1958 Bubble pressures in Greenland glacier ice. Intemational Association of Hydrology Publication 47 (Symposium of Chamonix Physics of the Motion of Ice): 336-349
Lebel B 1979 Porosité et teneur en gaz de la glace polaire récente; applications à l'étude des carottes prélevées en profondeur. Publication du Laboratoire de Glaciologie du Centre National de Za Recherche Scientifique 255

Legrand M 1980 Mesures de 1'acidité et de la conductivité électrique des précipitations antarctiques. Publication du Laboratoire de Glaciologie du Centre National de Za Recherche Seientifique 316

Raynaud $D 1977$ Les inclusions gazeuses dans la glace de glacier; leur utilisation comme indicateur du site de formation de la glace polaire; applications climatiques et rhéologiques. Publication du Laboratoire de Glaciologie du Centre National de la Recherche Scientifique 214

Raynaud D, Delmas R 1977 Composition des gaz contenus dans la glace polaire. International Association of Hydrological Sciences 118 (General Assembly of Grenoble 1975 - Isotopes and Impurities in Snow and Ice): 377-381

Raynaud D, Lebel B 1979 Total gas content and surface elevation of polar ice sheets. Nature 281(5729): 289-291

Raynaud D, Whillans I M 1982 Air content of the Byrd core and past changes in the West Antarctic ice sheet. Annals of Glaciology 3: 269-273

Raynaud D, Lorius C, Budd W F, Young N W 1979 Ice flow along an I.A.G.P. flow line and interpretation of data from an ice core in Terre Adelie, Antarctica. Journal of Glaciology 24(90): 103115

Stumm W, Morgan J J 1970 Aquatic chemistmy. New York etc, Wiley and Sons 